\title{
Method for auxiliary use of thermography in diagnosing inflammation in the coxofemoral joint in dogs
}

\section{Método para uso da termografia no diagnóstico auxiliar da inflamação na articulação coxofemoral em cães}

\author{
Fernanda Lúcia Passos Fukahori ${ }^{*}$; Daniela Maria Bastos de Souza ${ }^{2}$; \\ Eduardo Alberto Tudury ${ }^{3}$; George Chaves Jimenez ${ }^{4}$; José Ferreira da Silva Neto ${ }^{5}$; \\ Vanessa Carla Lima da Silva ${ }^{6}$; Michelle Suassuna de Azevedo Rêgo ${ }^{7}$; \\ Evilda Rodrigues de Lima ${ }^{8}$
}

\begin{abstract}
Joint diseases are relatively common in domestic animals, such as dogs. The involved inflammation produces thermal emission, which can be imaged using specific sensors that allow capturing of infrared images. Given that there have been few reports on the use of thermography in the diagnosis of inflammation associated with diseases of the hip joint in dogs, we here propose a method for identification of inflammatory foci in dogs by using infrared thermometry. The present study aimed to find non-invasive and low-cost resources that couldfacilitate a clinical diagnosis in cases withinflammation in the coxofemoral joint of dogs.To this end, we developed a system in whichthe Flir Systems TG165 thermograph is coupled to a black PVC cannula with a 30-cm focus-to-animal distance.External effects of the environment on the temperature of the animalswere compared with the body temperature as measured by a conventional thermometer.Thirty-one dogs with and without inflammation in the coxofemoral joint underwent clinical evaluation. We verified that the temperature registered by the thermograph inthe animals with joint inflammation was significantlydifferentfrom that incontrol animals without inflammation, in the lateral projection. The method showed a sensitivity of $80 \%$, specificity of $87.5 \%$, and accuracy of $83.87 \%$. This standardized method of diagnosis of inflammatory foci in the coxofemoral articulation of dogs by way of thermography showed sensitivity, specificity, and satisfactory accuracy.
\end{abstract}

Key words: Infrared. Joint disease. Radiation.

1 Discente, Curso de Doutorado, Programa de Pós-Graduação em Ciência Veterinária, Universidade Federal Rural de Pernambuco, UFRPE, Recife, PE, Brasil. E-mail: fukahorifvet@hotmail.com

2 Prof A Adjunto, Farmacologia Veterinária, Departamento de Fisiologia e Morfologia Animal, UFRPE, Recife, PE, Brasil. E-mail: daniela.vet@hotmail.com

3 Prof. Titular, Técnica Cirúrgica Veterinária, Departamento de Medicina Veterinária, UFRPE, Recife, PE, Brasil. E-mail: respeit@ hotmail.com

4 Prof. Adjunto IV, Farmacologia Veterinária, Departamento de Fisiologia e Morfologia Animal, UFRPE, Recife, PE, Brasil. E-mail: g3jime@yahoo.com.br

5 Técnico Administrativo, Departamento de Fisiologia e Morfologia Animal, UFRPE, Recife, PE, Brasil. ferreirapeneto@hotmail. com

6 Médica Veterinária autônoma, Drª em Ciência Veterinária, URFPE, Recife, PE, Brasil. E-mail: vcls2004@yahoo.com.br

7 Discente, Curso de Doutorado, Programa de Pós-Graduação em Ciência Veterinária, UFRPE, Recife, PE, Brasil. E-mail: michellesuassuna@hotmail.com

8 Prof $f^{a}$ Titular, Semiologia Veterinária, Departamento de Medicina Veterinária, UFRPE, Recife, PE, Brasil. E-mail: evilda17@ hotmail.com

* Author for correspondence 


\section{Resumo}

Tentando buscar recursos não invasivos e de baixo custo, para auxiliar o diagnóstico clínico em casos de inflamação na articulação coxofemoral de cães, idealizou-se o presente trabalho, que teve como objetivo propor um método de diagnóstico, em casos de inflamação na articulação coxofemoral de cães, desenvolvido a partir do registro do aumento da temperatura no local da inflamação, mediante o emprego de um termógrafo do tipo TG165 da Flir Systems acoplado a uma cânula de PVC, negra, com $30 \mathrm{~cm}$ de distância foco-animal para diminuir os efeitos externos que o ambiente exerce sobre a temperatura dos animais, e comparando-a com a temperatura corpórea, aferida por um termômetro convencional. Foram submetidos à avaliação clínica, 31 cães com e sem inflamação na articulação coxofemoral, onde verificou-se que a temperatura, registrada pelo termógrafo, dos animais pertencente ao grupo com inflamação na articulação apresentou diferença significativa na projeção lateral, em relação a temperatura dos animais do grupo sem doença articular, também aferida através do aparelho termográfico. O método apresentou sensibilidade de $80 \%$, especificidade de $87,5 \%$ e precisão de $83,87 \%$. Conclui-se que a padronização do método de diagnóstico de focos inflamatórios na articulação coxofemoral de cães pela termografia apresentou sensibilidade, especificidade e precisão satisfatória.

Palavras-chave: Doenças articulares. Radiação. Infravermelho.

\section{Introduction}

Joint diseases are relatively common in domestic animals, particularly in dogs (FRIES; REMEDIOS, 1995; RETTENMAIER et al., 2002). Al though the condition is more clinically relevant in medium and large breeds, such as Fila Brasileiro, Rottweiler, German Shepherd (WOOD et al., 2000; GINJA et al., 2009), there is no predilection for dog breeds. Lust et al. (1993) posited that the condition has a genetic component, although its occurrence has also been associated with aging in dogs.

Osteoarthritis, a multifactorial disease, may be associated with secondary causes, such as age, chronic lesions, local inflammation, obesity, hip dysplasia, and other factors (FRIES; REMEDIOS, 1995). The disease may have a symptomatic picture that does not correspond with radiological findings (WALLACE, 1987), and can rangefrom a slight discomfort to severe pain when touched, claudication, and voluntary paresis of the hind limbs, which can progress to degenerative joint disease (FRIES; REMEDIOS, 1995; ALLAN, 2002; NOGUEIRA; TUDURY, 2002; NOGUEIRA et al., 2005; ROCHA et al., 2013).

Inflammatory processes result from the release of mediators and cell signaling initiated by molecules deriving from the harmful process (SERHAN; CHIANG, 2004; OLIVA et al., 2004; RANG et al., 2008). These mediators trigger a cascade of events thatinclude reprogramming of local metabolic activity and disruption of the balance of immuneneuroendocrine responses, involvingchanges in the patterns of blood flow and thermal energy distribution, which is accompanied by anincrease in local temperature (CHANDRASEKHARAN et al., 2002; TAZIMA et al., 2008).

The thermal energy generated inthis way in a living organism could, initially, be eliminated by convective processes, conduction, and radiation emission in the infrared spectral range, with wavelengths ranging from 2 to $20 \mu \mathrm{m}$ (WINSOR; WINSOR, 1985; ANBAR et al., 1998). Furthermore, the relationship between high temperatures and is well known (RING, 2004).

Specific sensors that allow capturing of infrared images were developed based on the StefanBoltzmann law (JONES, 1998), and with advances in thermography techniques, thermal sensitivity of up to $0.02^{\circ} \mathrm{C}$ has been achieved. The noninvasiveness of thermography allows mapping of the body and detection of foci of thermal emission that maybe associated with inflammatory processes 
(RING; COLLINS, 1970; EDDY et al., 2001; ROBERTO; SOUZA, 2014). Since the development of the technique, several studies in veterinary and human medicine (BRIOSCHI et al., 2007; NUNES et al., 2007; BANDEIRA et al., 2012; SEGUNDO; AZEVEDO, 2015) have been performed.

Given the paucity of literature on the use of thermography in the diagnosis of inflammation associated with diseases of the hip joint in dogs, we proposed a method for the diagnosis of these inflammatory foci using infrared thermometry.

\section{Material and Methods}

The protocols described below complied with biosafety and ethical standards and were approved by the Ethics Committee for Animal Experimentation of University XXX under protocol number 063/2016.

Adult dogs $(n=31)$, of different breeds and both sexes, were obtained from the clinic of the Veterinary Hospital of the XXX University.

Upon admission of the animals, the personal data of the guardian and data of the animal, such as its name, age, sex, weight, and rectal temperature (measured using a clinical thermometer), were recorded in a registration form. An informed consent form was also filled out, in which the guardian was informed about the research conditions, and they agreed to the inclusion of the animal in the planned study. Each animal was then subjected to a detailed anamnesis and clinical orthopedic examination, as suggested by Nogueira and Tudury (2002). Animals with clinical signs compatible with hip inflammation underwent radiographic examinations, and those who exhibited clinical complaints of claudication were included in the study. The control group was comprised of dogs that did not have hip articulation problems.

After registration, all animals were transferred to an air-conditioned room at $25^{\circ} \mathrm{C}$ and relative air humidity above $70 \%$, for 20 minutes, to minimize the effects of the environment on the temperature of the animal. After this period, the temperature atthe axis of the hip joint in the anteroposterior and lateral projection was recorded using a digital thermograph(model TG165, Flir Systems, Wilsonville, OR, USA), with a resolution of $60 \times$ 80 pixels, to capture electromagnetic waves in the infrared spectrum, which makes it possible torecord temperature within 3 seconds of exposure. In this study, a 30-cm long PVC cannula, coated with matte black film, was coupled to the end of the device to minimize external interferences that could hinder the readings. The temperature of the animals was recorded simultaneously, minimizing the effects of circadian rhythms on temperature variation.

After positioning the animal appropriately for recording the temperature, the cannula and the equipment were juxtaposed over the desired region. The same focal length was maintained throughout, and emission proportional to an area of $1.23 \mathrm{~cm}^{2}$ was obtained. The emissivity of the equipment was adjusted to $\mathrm{e}=0.95$ in all measurements. The data obtained were tabulated and used in calculation.

For animals without joint disease, the interval between the temperature recorded by the equipment (Tt) and body temperature ( $\mathrm{Tb}$ )was obtained by the equation $\mathrm{DT}_{\text {wnjd }}=\mathrm{Tt}_{\text {free jd }}-\mathrm{Tb}_{\text {free jd }}$. This difference was normalized by the relation $\mathrm{DT}_{\text {free jd }} / \mathrm{Tb}_{\text {free jd }}$ to allow comparison of readings could be compared. The mean and standard deviation of these control animals were obtained by the equationDT $\mathrm{T}_{\text {free jd }} \mathrm{M} /$ $\mathrm{Tb}_{\text {free jd}}$.

For animals clinically diagnosed with joint problems, the same procedure was applied, and the difference obtained as $\mathrm{DT}_{\mathrm{wjd}}=\mathrm{Tt}_{\mathrm{wjd}}-\mathrm{Tb}_{\mathrm{wjd}}$.

The inflammation difference (ID), which may be associated with inflammation ofthe hip joint wasobtained as thedifference between the value $\mathrm{DT}_{\text {wjd }} / \mathrm{Tb}_{\mathrm{wjd}}$ measured for each animal with joint problemsand the mean value of the parameterDT ${ }_{\text {sdal }}$ / $\mathrm{Tc}_{\text {sda }}$ obtained for the control group animals $\left(\mathrm{DT}_{\text {free }}\right.$ ${ }_{\mathrm{jd}}^{\mathrm{M}} / \mathrm{Tc}_{\text {free jd }}$ );i.e., ID $=\mathrm{DT}_{\mathrm{wjd}} / \mathrm{Tb}_{\text {wjd }}-\mathrm{DT}_{\text {free jd }}{ }^{\mathrm{M}} / \mathrm{Tb}_{\text {free }}$ 
jd . When the ID is positive, the animal could be considered to be suffering inflammation. If the value was negative, the animal was considered "free of inflammation" by thermographic evaluation.

Calculations were performed separately for temperature recorded for the anteroposterior and lateral projections.

Using Student' st-test in Microsoft Excel 2010 software, the statistical significance of differences in mean values was evaluated with a significance level set at $p<0.05$. The sensitivity and specificity of the diagnosis determined in this way were calculated, following the recommendations of Reis (2003) and Hastie (2009), to assess the viability of the method as a diagnostic aid.

\section{Results and Discussion}

The mean age of the dogs was $9.5 \pm 2.5$ years. Of the 31 dogs, 22 were males and nine were females, and their mean weight was $16.76 \pm 6.73 \mathrm{~kg}$.

We sought to develop a diagnostic method based on temperature values measured by a thermograph, as no effective method for assigning a parameter indicating association between temperature variation in the hip joint and the presence of local inflammation has been reported in the literature.

The use of thermography and associated techniques has been used in $\mathrm{Tj}_{\mathrm{AAD}}$ diseases in veterinary medicine previously, for instance, the study by Purohit and Mccoy (1980), which diagnosed inflammation in the superficial digital flexor tendons in race horses. Other important studies werethatof Ring and Ammer (2008), which investigated the occurrence of diseases involving the neuromuscular and skeletal systems using thermal imaging, and that of Turner (2010), which investigated the detection of low back pain in horses with spinal problems, and foundthermographic evaluations to have a sensitivity of 98.5\%. Rantanen (2010) proposed algorithms for evaluating thermographic images related to the presence of foci of inflammation in superficial and deep areas in horses.

Todevelop the method, it was necessary to consider the natural decreasein theanimal's body temperature, as estimated fromthe rectal temperature taken at the level of the joint,and to define to what extent this temperature would drop in animals not suffering from joint disease, as expressed by $\mathrm{DT}_{\text {free jd }}$ $=\mathrm{Tt}_{\text {free jd }}-\mathrm{Tb}_{\text {free jd }}$. We normalized this difference, i.e., $\mathrm{DT}_{\text {free jd }}$ was divided by $\mathrm{Tb}_{\text {free jd }}$ (body temperature), so that these values could be compared across animals. Thus, the mean value for the normalized difference $\mathrm{DT}_{\text {free jd }} \mathrm{M} / \mathrm{Tb}_{\text {free jd }}$ was obtained so that this measure could be used when measuring the normalized temperature difference obtained in animals with joint disease, by the equation ID $=\left[\left(\mathrm{Tb}_{\mathrm{wjd}}-\mathrm{Tt}_{\mathrm{wjd}}\right) /\right.$ $\left.\mathrm{Tb}_{\text {wjd }}\right]-\mathrm{D}_{\text {free jd }} \mathrm{M} / \mathrm{Tb}_{\text {free jd }}$.

This equation above should be writtenas[DI $\left.+\mathrm{D}_{\text {free jd }} \mathrm{M} / \mathrm{Tb}_{\text {free jd }}\right] / \mathrm{TA}_{1}=\left[\left(\mathrm{Tb}_{\mathrm{wjd}}-\mathrm{Tt}_{\mathrm{wjd}}\right) / \mathrm{Tb}_{\mathrm{wjd}}\right] / \mathrm{TA}_{2}$, where $\mathrm{TA}_{1}$ and $\mathrm{TA}_{2}$ correspond to the contributions of room temperature at the time of thermographic evaluations. Since the tests were carried out in an air-conditioned environment at $25^{\circ} \mathrm{C}$, where all animals were allowed to restfor at least 20 minutes to reduce their stress and provide thermal accommodation, $\mathrm{TA}_{1}$ was considered to be equal to $\mathrm{TA}_{2}$ and the equation was simplified as follows: ID $=\left[\left(\mathrm{Tb}_{\mathrm{wjd}}-\mathrm{Tt}_{\mathrm{wjd}}\right) / \mathrm{Tb}_{\mathrm{wjd}}\right]-\mathrm{D}_{\text {free jd }} \mathrm{M} / \mathrm{Tb}_{\text {free jd }}$.

The values of ID obtained, respectively, for animals without and with joint disease, relevant to the hip joint at the anteroposterior projection,s shown in Tables 1 and 2.No significant differences were found between the normalized temperature difference values between these two groups $(p=$ 0.0827). 
Table 1. Standardized temperature differences at the anteroposterior projection in the hip joint of animals without joint disease.

\begin{tabular}{|c|c|c|c|c|c|}
\hline Animal & $\begin{array}{l}\text { Weight } \\
\text { (Kg) }\end{array}$ & Sex & $\begin{array}{l}\mathrm{Tc}_{\text {sda }} \\
(\mathrm{W})\end{array}$ & $\begin{array}{l}\mathbf{T t}_{\text {sda }} \\
(\mathrm{W})\end{array}$ & $\begin{array}{c}\left(\mathrm{Tc}_{\mathrm{sda}}-\mathrm{Tt}_{\mathrm{sda}}\right) / \mathrm{Tc}_{\mathrm{sda}} \\
(\mathrm{C} / \mathbf{1 C})\end{array}$ \\
\hline 1 & 12.0 & $\mathrm{M}$ & 38.6 & 31.1 & 0,194 \\
\hline 2 & 16.4 & M & 38.7 & 29.2 & 0.246 \\
\hline 3 & 20.0 & $\mathrm{M}$ & 38.0 & 31.1 & 0,182 \\
\hline 4 & 13.0 & M & 38.4 & 36.6 & 0.047 \\
\hline 5 & 14.0 & $\mathrm{~F}$ & 38.3 & 32.3 & 0.157 \\
\hline 6 & 13.4 & $\mathrm{~F}$ & 38.0 & 30.0 & 0.211 \\
\hline 7 & 15.0 & $\mathrm{~F}$ & 38.1 & 36.5 & 0.042 \\
\hline 8 & 12.0 & M & 38.6 & 31.1 & 0,194 \\
\hline 9 & 15.0 & $\mathrm{~F}$ & 38.1 & 30.3 & 0.205 \\
\hline 10 & 16.2 & M & 38.7 & 29.2 & 0.246 \\
\hline 11 & 18.0 & M & 38.0 & 33.2 & 0.126 \\
\hline 12 & 14.8 & $\mathrm{M}$ & 38.6 & 33.8 & 0.124 \\
\hline 13 & 12.0 & $\mathrm{M}$ & 38.6 & 28.7 & 0.257 \\
\hline 14 & 12.9 & $\mathrm{~F}$ & 38.6 & 33.0 & 0.145 \\
\hline 15 & 19.0 & $\mathrm{M}$ & 38.4 & 30.3 & 0.211 \\
\hline \multirow[t]{2}{*}{16} & 16.9 & $\mathrm{M}$ & 38.5 & 36.6 & 0.049 \\
\hline & & & & Mean \pm MSE & $0.164 \pm 0.018$ \\
\hline
\end{tabular}

Male (M), Female (F); $\mathrm{Tc}_{\mathrm{sda}}$ - Body temperature of animals without joint disease;

$\mathrm{Tt}_{\text {sda }}$ - Temperature at the joint of animals without joint disease; $\mathrm{C}$ - Degrees Celsius; C/1C -Degrees Celsiusper degree Celsius of body temperature.

Table 2. Standardized temperature difference atanteroposterior projection in the hip joint of animals with joint disease and the difference in inflammation.

\begin{tabular}{|c|c|c|c|c|c|}
\hline Animal & $\begin{array}{c}\text { Weight } \\
\text { (Kg) }\end{array}$ & Sex & $\begin{array}{l}\mathrm{Tc}_{\text {cda }} \\
\text { (W) }\end{array}$ & $\begin{array}{l}\mathbf{T t}_{\text {cda }} \\
(\mathrm{W})\end{array}$ & $\begin{array}{c}\left(\mathrm{Tc}_{\mathrm{cda}}-\mathrm{Tt}_{\mathrm{cda}}\right) / \mathrm{Tc}_{\mathrm{cda}} \\
(\mathrm{C} / 1 \mathrm{C})\end{array}$ \\
\hline 1 & 15.9 & $\mathrm{~F}$ & 38.5 & 32.4 & 0.158 \\
\hline 2 & 14.3 & M & 38.0 & 33.2 & 0.126 \\
\hline 3 & 14.0 & $\mathrm{M}$ & 38.3 & 36.9 & 0.037 \\
\hline 4 & 38.4 & $\mathrm{~F}$ & 38.1 & 27.9 & 0.268 \\
\hline 5 & 22.0 & $\mathrm{M}$ & 39.3 & 29.6 & 0.247 \\
\hline 6 & 10.9 & $\mathrm{~F}$ & 38.9 & 28.8 & 0.260 \\
\hline 7 & 14.0 & M & 38.2 & 36.9 & 0.034 \\
\hline 8 & 27.3 & $\mathrm{M}$ & 38.7 & 29.5 & 0.238 \\
\hline 9 & 35.2 & $\mathrm{M}$ & 38.4 & 30.8 & 0,198 \\
\hline 10 & 18.5 & M & 39.2 & 27.5 & 0.299 \\
\hline 11 & 10.0 & M & 39.1 & 27,1 & 0.307 \\
\hline 12 & 25.2 & $\mathrm{~F}$ & 37.9 & 28.0 & 0.261 \\
\hline
\end{tabular}


continuation

$\begin{array}{llllll}13 & 11.2 & \mathrm{M} & 39.2 & 29.1 & 0.258 \\ 14 & 10.1 & \mathrm{M} & 39.0 & 29.3 & 0.249 \\ 15 & 17.0 & \mathrm{M} & 38.5 & 26.6 & 0.309\end{array}$

Male (M), Female (F); $\mathrm{Tc}_{\mathrm{cda}}$ - Body temperature of animals with joint disease; $\mathrm{Tt}_{\mathrm{cda}}$ - Temperature at the joint of animals with joint disease; Inflammation difference ID $=\left[\left(\mathrm{Tc}_{\text {cda }}-\mathrm{Tt}_{\mathrm{cda}}\right) / \mathrm{Tc}_{\text {cda }}\right]-\mathrm{D}_{\text {sda }} \mathrm{M} / \mathrm{Tc}_{\text {sda }}$, where $\mathrm{D}_{\text {sda }}{ }^{\mathrm{M}} / \mathrm{Tc}_{\text {sda }}$ represents the mean of the normalized valuesobtained for the control group; $\mathrm{C}$ - Degrees Celsius; $\mathrm{C} / 1 \mathrm{C}$ - Degrees Celsius per degree Celsius of body temperature.

For thelateral projection, there was asignificant differencein thenormalized joint temperature differences between animals with and those without joint disease $(\mathrm{p}=0.0407)$ as shown in Tables 3 and 4, demonstrating that,in the thermographic evaluation usingthe proposed methodology, the angle of capture of the temperature atthe joint has an effect,as, anatomically, the regional circulatory contributions and the superposition of the tissues associated with the joint affect thehomogeneity of the temperaturedistribution by influencing the propagation of thermal energy by conduction, convection, and even by emission of infrared radiation in local tissues.

Table 3. Standardized temperature difference of the hip joint at the lateral projection of animals without joint disease.

\begin{tabular}{|c|c|c|c|c|c|}
\hline Animal & $\begin{array}{l}\text { Weight } \\
\text { (Kg) }\end{array}$ & Sex & $\begin{array}{l}\mathrm{Tc}_{\text {sda }} \\
(\mathrm{W})\end{array}$ & $\begin{array}{l}\mathbf{T t}_{\text {sda }} \\
(\mathrm{W})\end{array}$ & $\begin{array}{c}\left(\mathrm{Tc}_{\text {sda- }} \mathrm{Tt}_{\text {sda }}\right) / \mathrm{Tc}_{\mathrm{sda}} \\
(\mathrm{C} / \mathbf{1 C})\end{array}$ \\
\hline 1 & 12.0 & $\mathrm{M}$ & 38.6 & 28.7 & 0.257 \\
\hline 2 & 16.4 & $\mathrm{M}$ & 38.7 & 30.3 & 0.217 \\
\hline 3 & 20.0 & $\mathrm{M}$ & 38.0 & 33.0 & 0,132 \\
\hline 4 & 13.0 & $\mathrm{M}$ & 38.4 & 34.8 & 0.094 \\
\hline 5 & 14.0 & $\mathrm{~F}$ & 38.3 & 28.6 & 0.253 \\
\hline 6 & 13.4 & $\mathrm{~F}$ & 38.0 & 28.6 & 0.247 \\
\hline 7 & 15.0 & $\mathrm{~F}$ & 38.1 & 32.0 & 0.160 \\
\hline 8 & 12.0 & $\mathrm{M}$ & 38.6 & 36.2 & 0.062 \\
\hline 9 & 15.0 & $\mathrm{~F}$ & 38.1 & 28.9 & 0.241 \\
\hline 10 & 16.2 & $\mathrm{M}$ & 38.7 & 28.3 & 0.269 \\
\hline 11 & 18.0 & $\mathrm{M}$ & 38.0 & 30.9 & 0.187 \\
\hline 12 & 14.8 & $\mathrm{M}$ & 38.6 & 27.6 & 0.285 \\
\hline 13 & 12.0 & $\mathrm{M}$ & 38.6 & 34.5 & 0.106 \\
\hline 14 & 12.9 & $\mathrm{~F}$ & 38.6 & 31.1 & 0,194 \\
\hline 15 & 19.0 & $\mathrm{M}$ & 38.4 & 29.2 & 0.240 \\
\hline \multirow[t]{2}{*}{16} & 16.9 & $\mathrm{M}$ & 38.5 & 34.8 & 0.096 \\
\hline & & & & Mean \pm MSE & $0.119 \pm 0.017$ \\
\hline
\end{tabular}

Male (M), Female (F); $\mathrm{Tc}_{\mathrm{sda}}$ - Body tejmperature of animals without joint disease; $\mathrm{Tt}_{\mathrm{sda}}$ - Temperature at the joint of animals without joint disease; C - Degrees Celsius; C/1C - degrees Celsius per degree Celsius of body temperature; MSE-mean standard error. 
Table 4. Standardized temperature difference ofthe hip joint atthe lateral projection of animals with joint disease and the thermal difference in inflammation.

\begin{tabular}{ccccccc}
\hline Animal & $\begin{array}{c}\text { Weight } \\
(\mathrm{Kg})\end{array}$ & $\mathrm{Sex}$ & $\mathrm{Tc}_{\text {cda }}(\mathrm{W})$ & $\begin{array}{c}\mathrm{Tt}_{\text {cda }} \\
(\mathrm{W})\end{array}$ & $\begin{array}{c}\left(\mathrm{Tc}_{\text {cda }}-\mathrm{Tt}_{\text {cda }}\right) / \mathrm{Tc}_{\text {cda }} \\
(\mathrm{C} / 1 \mathrm{C})\end{array}$ & $\begin{array}{c}\mathrm{ID} \\
(\mathrm{C} / 1 \mathrm{C})\end{array}$ \\
\hline 1 & 15.9 & $\mathrm{~F}$ & 38.5 & 34.7 & 0.099 & -0.091 \\
2 & 14.3 & $\mathrm{M}$ & 38.0 & 30.6 & 0,195 & 0.005 \\
3 & 14.0 & $\mathrm{M}$ & 38.3 & 33.0 & 0.138 & $-0,052$ \\
4 & 38.4 & $\mathrm{~F}$ & 38.1 & 27.2 & 0.286 & 0.096 \\
5 & 22.0 & $\mathrm{M}$ & 39.3 & 26.8 & 0.318 & 0.128 \\
6 & 10.9 & $\mathrm{~F}$ & 38.9 & 28.4 & 0.270 & 0.080 \\
7 & 14.0 & $\mathrm{M}$ & 38.2 & 33.0 & 0.136 & -0.054 \\
8 & 27.3 & $\mathrm{M}$ & 38.7 & 28.1 & 0.274 & 0.084 \\
9 & 35.2 & $\mathrm{M}$ & 38.4 & 30.4 & 0,208 & 0.018 \\
10 & 18.5 & $\mathrm{M}$ & 39.2 & 28.0 & 0.286 & 0.096 \\
11 & 10.0 & $\mathrm{M}$ & 39.1 & 27.9 & 0.286 & 0.096 \\
12 & 25.2 & $\mathrm{~F}$ & 37.9 & 27,1 & 0.285 & 0.095 \\
13 & 11.2 & $\mathrm{M}$ & 39.2 & 26.8 & 0.316 & 0.126 \\
14 & 10.1 & $\mathrm{M}$ & 39.0 & 28.8 & 0.261 & 0.072 \\
15 & 17.0 & $\mathrm{M}$ & 38.5 & 25.8 & 0.330 & 0.140 \\
\hline
\end{tabular}

Male $(M)$, Female $(F) . ~ T c_{c d a}$ - body temperature of animals with joint disease. $\mathrm{Tj}_{\mathrm{AAD}}-\mathrm{Temperature}$ at the joint of animals with joint disease. Thermal difference in inflammation $\mathrm{ID}=\left[\left(\mathrm{Tc}_{\mathrm{cda}}-\mathrm{Tt}_{\mathrm{cda}}\right) / \mathrm{Tc}_{\mathrm{cda}}\right]-\mathrm{D}_{\mathrm{sda}} \mathrm{M} / \mathrm{Tc}_{\mathrm{sda}}$, where $\mathrm{D}_{\mathrm{sda}} \mathrm{M}^{\mathrm{T}} \mathrm{Tc}_{\mathrm{sda}}$ represents the mean of the values normalized for the control group. $\mathrm{C}$ - Degrees Celsius; C/1C- degrees Celsius for each degree Celsius of body temperature.

Table 4 shows a comparison of the ID values, whose unit $(\mathrm{C} / 1 \mathrm{C})$ corresponds to the local temperature variation per degree of body temperature change in the evaluated animal, in animal swith and those without joint disease. Among the animals with a positive ID, some demonstrated greater variations than others, which may be associated with the intensity of the inflammatory process in the tissues related to the hip joint. It is important to note that some animals were clinically symptomatic of joint inflammation (3 of 15 animals, 20\%), but had a negative ID value, i.e., an ID that was below the critical limit of thermal variation in the joints of animals without joint disease.

Given that two of the animals without joint disease showed normalized temperature difference values above the critical limit, we determined the sensitivity and specificity as $80.0 \%$, and $87.5 \%$, and the accuracy of the method was $83.87 \%$. Since sensitivity measures the proportion of animals clinically diagnosed with joint inflammation that showeda positive ID value, and specificity measures the proportion of animals without joint diseasethat hadanegative ID value, the results obtained in this study couldbe considered satisfactory, and similar to those obtained by Head et al. (1999), who reported a sensitivity of $86.0 \%$ and a specificity of $89 \%$ when using thermography to identify and monitor breast cancer.These results also emphasizedthe importance of thismethodology as a tool that could aid in the diagnosis of inflammatory processes, in agreement with the report by Ring and Ammer (2008), who investigateddiagnosis of diseases of the neuromuscular and skeletal systems by thermography.

There were no significant differences in the temperature values obtained formales and for females $(p=0.382$ for evaluations in the anteroposterior direction and $\mathrm{p}=0.648$ for evaluations in the lateral direction). 
Thermography has been shown to be useful for the evaluation of abnormal alterations in the patterns of superficial temperature variation caused by tissue injuries in local musculature and tissues, although some authors, such as Valberg (2006), have pointed out that this procedure may have limited applicability to the identification of deeper lesions.

The emission of thermal energy in the form of infrared radiation does not occur uniformly but varies according to the characteristics of local and circulatory metabolism and its regulation by the immune and neuroendocrine systems, as pointed out by Anbar (1994). According to Cetinkaya and Demirutku (2012), thermography is particularly useful for identification of deep inflammatory foci the thermographic images show fields of contrast between areas with different thermal density, which was associated with the local temperatures measured in the regions containing inflammatory foci.

This thermographic imaging protocol allows monitoring of the evolution of inflammatory processes in the lateral projection of the hip joint, even during therapy, as demonstrated by Basile et al. (2010a,b), who evaluated the evolution of theinflammatory picture ofthe thoracic limbs of horses over a period of 150 hours, and demonstratedthe oscillation of temperature in the inflamed areas during therapy, up tothe final phase of the treatment.

\section{Conclusions}

The results of the present study indicate that this infrared thermography method can be used for diagnosis of inflammatory foci at the hip joint in dogs, with good sensitivity, specificity, and satisfactory accuracy when the images are captured at the lateral projection of the joint. The simplicity of the method, the stability of the results, and the rapidity of the diagnosis make this a useful clinical approach that can improve animal welfare.

\section{Acknowledgment}

We thank the FACEPE for the scholarship related to this study.

\section{References}

ALLAN, G. Radiographic signs of joint disease. In: THRALL, D. E. Textbook of veterinary diagnostic radiology. $4^{\text {th }}$ ed. Thrall, Philadelphia: W. B. Saunders, 2002. p. 187-207.

AMBAR, M. Quantitative dynamic telethermometry. In: BUZUG, T. M.; SCHUMANN, S.; PFAFFMANN, L.; REINHOLD, U.; RUHLMANN, J. Medical diagnosis and management. Boca Raton: CRC Press, 1994. p. 2766-2769.

ANBAR, M.; GRATT, B. M.; HONG, D. Thermology and facial telethermography. Part I: history and technical review. Dentomaxillofacial Radiology, New York, v. 27, n. 2, p. 61-67, 1998.

BANDEIRA, F.; MOURA, M. A. M.; SOUZA, M. A.; NOHAMA, P.; NEVES, E. B. Pode a termografia auxiliar no diagnóstico de lesões musculares em atletas de futebol? Revista Brasileira de Medicina do Esporte, São Paulo, v. 18, n. 4, p. 79-86, jul./ago. 2012.

BASILE, R. C.; ALBERNAZ, R. M.; PEREIRA, M. C.; ARAUJO, R. A.; FAGLIARI, J. J.; GONDIN, M. R.; FERRAZ, G. C.; QUEIROZ-NETO, A. Estudo comparativo dos limiares de detecção de métodos de avaliação de inflamação musculoesquelética em equinos. In: CONFERÊNCIA ANUAL ABRAVEQ, 13., 2012, Águas de Lindóia. Anais... Águas de Lindóia, 2012b. p. 135-136.

BASILE, R. C.; FLORES, F. N.; GIANGRECCO, E.; VALADAO, C. A.; MACORIS, D. G.; JOAQUIM, J. G. F. Estratégias de tratamento de lesões traumáticas da medula espinhal de equinos - relato de caso. Revista de Educação Continuada em Medicina Veterinária e Zootecnia, São Paulo, v. 10, n. 1, p. 85-86 2012a.

BRIOSCHI, M. L.; YENG, L. T.; PASTOR, E. M. H.; TEIXEIRA, M. J. Utilização da imagem infravermelha em reumatologia. Revista Brasileira de Reumatologia, São Paulo, v. 47, n. 1, p. 42-51, 2007.

CETINKAYA, M. A.; DEMIRUTKU, A. Thermography in the assessment of equine lameness. Turkish Journal of Veterinary and Animal Sciences, Ankara, v. 36, n. 1, p. 43-48, 2012. 
CHANDRASEKHARAN, N. V.; DAÍ, H.; ROOS, K. L.; EVANSON, N. K.; TOMSIK, J.; ELTON, T. S. COX-3, a cyclooxygenase-1 variant inhibited by acetaminophen and other analgesic/ antipyretic drugs: cloning, structure, and expression. Proceedings of the National Academy of Sciences of the United States of America, Washington, v. 99, n. 21, p. 13926-13931, 2002.

EDDY, A. L.; VAN HOOGMOED, L. M.; SNYDER, J. R. The role of thermography in the management of equine lameness. The Veterinary Journal, London, v. 162, n. 3, p. 172-181, 2001.

FRIES, C. L.; REMEDIOS, A. M. The pathogenesis and diagnosis of canine hip dysplasia: a review. Canadian Veterinary Journal, Guelph, v. 36, n. 8, p. 494-501, 1995.

GINJA, M. M. D.; SILVESTRE, A. M.; COLAÇO, J. Hip dysplasia in Estrela Mountain dogs: prevalence and genetic trends 1991-2005. Veterinary Journal, London, v. 182 , n. 2, p. 275-282, 2009.

HASTIE, T.; TIBSHIRANI, R.; FRIEDMAN, J. H. The elements of statistical learning data mining, inference, and prediction. $2^{\text {th }}$ ed. New York: Springer, 2009. $101 \mathrm{p}$.

HEAD, J. F.; LIPARI, C. A.; ELLIOT, R. L. Comparison of mammography and breast infrared imaging: sensitivity, specificity, false negatives, false positives, positive predictive value and negative predictive value. Proceedings of the first Joint BMES/EMBS Conference Serving Humanity, Advancing Technology, Atlanta oct. 13-16, 1999.

JONES, B. F. A reappraisal of the use of infrared thermal image analysis in medicine. IEEE Transactions on Medical Imaging, Pontypridd, v. 17, n. 6, p. 1019-1027, dec. 1998.

LUST, G.; WILLIAN, A. J.; WURSTER, N. B. Joint laxity and its association with hip dysplasia in Labrador retrievers. American Journal of Veterinary Research, Chicago, v. 54, n. 12, p. 1990-1999, 1993.

NOGUEIRA, S. R.; ROCHA, L. B.; TUDURY, E. A. Utilização do índice de distração no diagnóstico da displasia coxofemoral canina. Clínica Veterinária, São Paulo, v. 54, p. 28-42, jan./fev. 2005.

NOGUEIRA, S. R.; TUDURY, E. A. Exame clínico ortopédico em cães e gatos - part 1. Clínica Veterinária, São Paulo, v. 36, p. 34-58, jan./fev. 2002.

NUNES, L. A. O.; FILHO, A. C. C.; SARTORI, J. L. Câmara termográfica nacional. Revista Prática Hospitalar, São Paulo, v. 1, n. 49, p. 18-21, 2007.

OLIVA, V. N. L. S.; MAIA, C. A. A.; SILVA, B. M.; SAITO, L. M.; PERRI, S. H. V. Avaliação clínica de diferentes anti-inflamatórios não esteroides na analgesia pós-operatória de cirurgias ortopédicas em cães. Clínica Veterinária, São Paulo, v. 50, Ano IX, p. 42-52, 2004.

PUROHIT, R. C.; MCCOY, M. D. Thermography in the diagnosis of inflamatory process in the horse. American Journal of Veterinary Research, Chicago, v. 41, n. 8, p. 1167-1174, 1980.

RANG, H. P.; DALE, M. M.; RITTER, J. M.; FLOWER, R. J. Farmacologia. São Paulo: Ed. Elsevier, 2008. 226 p.

RANTANEN, N. W. Equine imaging modalities: an algorithm approach. In: ANNUAL CONVENTION OF AAEP, 56., 2010, California. Proceedings... California: AAEP, 2010. p. 290-296.

REIS, J. C. Estatística aplicada à pesquisa em ciência veterinária. In: Estatística vital. Olinda: Luci Artes Gráficas, 2003. cap. 5, p. 57-71.

RETTENMAIER, J. L.; KELLER, G. G.; LATTIMER, J. C.; CORLEY, E. A.; ELLERSIECK, M. R. Prevalence of canine hip dysplasia in a veterinary teaching hospital population. Veterinary Radiology \& Ultrasound, Bethesda, v. 43, n. 4, p. 313-318, 2002.

RING, E. F. J. The historical development of thermal imaging in medicine. Rheumatology, Oxford, v. 43, n. 6, p. 800-802, 2004.

ROBERTO, J. V. B.; SOUZA, B. B. Utilização da termografia de infravermelho na medicina veterinária e na produção animal. Journal of Animal Behaviour and Biometeorology, Mossoró, v. 2, n. 3, p. 73-84, 2014.

ROCHA, L. B.; TUDURY, E. A.; ROEHSIG, C.; BARAÚNA, D.; CHIORATTO, R.; ARAÚJO, F. P.; KEMPER, B. Denervação articular coxofemoral em cães com doença articular degenerativa secundária à displasia. Ciência Animal Brasileira, Goiânia, v. 14, n. 1, p. 120134, jan./mar. 2013.

SEGUNDO, F. A. S.; AZEVEDO, A. S. Termografia na avaliação de processo inflamatório. In: CONGRESSO BRASILEIRO DE MEDICINA VETERINÁRIA E CONGRESSO SUL-BRASILEIRO DA ANCLIVEPA, 42., 1., 2015, Curitiba. Anais... Curitiba: [s.n.], 2015. p. 278-282.

SERHAN, C. N.; CHIANG, N. Novel endogenous small molecules as the checkpoint controllers in inflammation and resolution: entrée for resoleomics. Rheumatic Disease Clinics of North America, Philadelphia, v. 30. n. 1, p. 69-95, 2004.

TAZIMA, M. F. G. S.; VICENTE, Y. A. M. V. A.; MORIYA, T. Biologia da ferida e cicatrização. Medicina, Ribeirão Preto, v. 3, n. 41, p. 259-264, 2008. 
TURNER, T. A. Diagnosis and treatment of back pain in horses. In: ITALIAN ASSOCIATION OF EQUINE VETERINARIANS CONGRESS, 16., Minnesota... Proceeding... 2010, Minnesota: St. Paul, 2010. p. 157160.

VALBERG, S. J. Diagnostic approach to muscle disorders. In: ANNUAL CONVENTION OF THE AAEP, 52., 2006, Minnesota, Proceedings... Minnesota: AAEP, 2006. p. 340-346.

WALLACE, L. J. Canine hip dysplasia: past and present. Seminars in Veterinary Medicine and Surgery Small Animals, Philadelphia, v. 2, n. 2, p. 513-528, 1987.
WINSOR, T.; WINSOR, D. The noninvasive laboratory: history and future of thermography. International Angiology, Torino, v. 4, n. 1, p. 41-50, 1985.

WOOD, J. L.; LAKHANI, K. H.; DENNIS, R. Heritability and epidemiological of canine hip dysplasia score and its components in flat-coated retrievers and New foundlands in the United Kingdom. Preventive Veterinary Medicine, Amsterdam, v. 46, n. 2, p. 75-86, 2000. 